\title{
Türk-İslam Sentezi'nin Oluşum ve Gelişim Süreci
}

\author{
DOI: $10.26466 /$ opus.699138
}

*

\author{
Ahmet Selim Kadıŏglu * \\ * Dr, Ankara, Türkiye \\ E-Posta: dr.askadioglu@gmail.com \\ ORCID: $\underline{0000-0003-0877-4513}$

\section{Öz}

Türk-İslam Sentezcilerine göre bir olgu olarak Türk-İslam Sentezi, Türklerin İslam'a girmesiyle oluşmaya başlayıp özellikle Selçuklu ve Osmanlı Devletleriyle olgunlaşarak Müslüman-Türk kimliği haline gelmiştir. Türklük ile İslamlık arasındaki bu sentez tez ve antitez zıtlığı şeklinde iki zıt unsurun bireşimi anlamında değil, iki uyumlu unsurun tarih boyunca tabii bir seyirle bireşim haline gelmesi biçiminde gerçekleşmiştir. Bu nedenle onlara göre Türkler İslam dinine büyük hizmetler yaptıklar gibi, İslam dini de Türk kimliğinin korunmasını sağlamıştır. İdeolojik açıdan ise Türk-İslam Sentezi, Osmanlı'nın son dönemlerinde gündeme gelen Türklük ve İslamlı siyasetlerinin Osmanlı Türkçüleri tarafindan ve onların perspektifinden mezcedilmesiyle oluşmuş, 1960'ln yıllardan sonra ise Milliyetçilerce olgunlaştırılmıştır. 1970'li yıllarda Türk düşünce ve siyasi hayatında etkinliklerini gittikçe artırmaya başlayan Türk-İslam Sentezcileri devlet ve millet kavramların yücelten, İslam dinine fonksiyonel cepheden de bakan, Cumhuriyet ilke ve kazanımlarm toptan reddetmeyen özellikleriyle 1980 sonrasinda devlet politikaların etkilemiş ve yönlendirmişlerdir. Ancak bu durum onlara göre Türk-İslam Sentezi'nin belli politik amaçlarla kurgulanmış ve üretilmiş olduğu anlamına gelmez, zira Türk-İslam Sentezi Türklerin yüzyıllardır sahip olageldiği kültür ve medeniyet değerlerinin toplamın ifade etmektedir. Günümüzde ise Cumhur İttifakl, Türk-İslam Sentezi'nin farklı ve özgün bir örneği olarak değerlendirilebilir.

Anahtar Kelimeler: Türk-İslam Sentezi, Türk-İslam Sentezcileri, Türkçülük, Milliyetçilik 


\title{
Formation and Development Process of Turkish-Islamic Synthesis
}

\begin{abstract}
According to the Turkish-Islamic Synthesizers, the Turkish-Islamic Synthesis started to emerge when Turks joined Islam and became a Muslim-Turkish identity especially by cementing with the Seljuk and Ottoman States. This synthesis between Turkishness and Islam did not occur by the meaning of the combination of two opposing elements in the form of thesis and antithesis contrast, but instead in the form of two harmonious elements becoming a natural course throughout history. Therefore, according to them, Turks did great services to the religion of Islam, and Islam provided the protection of Turkish identity. From the ideological point of view, the Turkish-Islamic Synthesis was formed by the Ottoman Turkists and their perspective by merging the Turkism and Islam, which came to the agenda in the last period of the Ottoman Empire, and was cemented by the Nationalists after the 1960s. The Turkish-Islamic Synthesists, who started to increase their activities in the Turkish thought and political life in the 1970s, influenced and directed the state policies after 1980 with the features that glorified the concepts of state and nation, who also viewed the functional aspect of Islam and did not reject the principles and achievements of the Republic altogether. However, according to them, this does not mean that the Turkish-Islamic Synthesis has been constructed and produced for certain political purposes, because the Turkish-Islamic Synthesis is the accumulation of the values of culture and civilization that Turks have had for centuries. Today, People's Alliance can be considered as a different and original example of Turkish-Islamic Synthesis.
\end{abstract}

Keywords: Turkish-Islamic Synthesis, Turkish-Islamic Synthesizers, Turkism, Nationalism 


\section{Giriş}

Geçtiğimiz yüzyıl başlarında Osmanlı Devleti'nin “beka” sorununa yönelik olarak aydınların ve devlet adamlarının zihinlerinde var olan kurtuluş reçetelerini, Yusuf Akçura 1904 yılında Mısır'da yayınladığı "Üç Tarz-ı Siyaset" adlı ünlü makalesinde Osmanlıcllık, İslamcılık ve Türkçülük olarak özetlemişti. Osmanlıcılık siyasetini eleyen Akçura, diğer ikisi arasında, birisi lehine diğerini tamamen elemenin imkansızlığını samimi olarak itiraf sadedinde olmak üzere yazısını şöyle bitiriyordu: "Hulasa, öteden beri zihnimi işgal edip de kendi kendimi ikna edecek cevabını bulamadı̆̆ım sual yine önüme dikilmiş cevap bekliyor; Müslümanlık, Türklük siyasetlerinden hangisi Osmanl Devleti için daha yararl ve kabil-i tatbiktir?"

Aslında bu soruyu o zamanki aydınların ve devlet adamlarını büyük çoğunluğu da net olarak cevaplayamamışlardı. Bundan dolayı sınırlı sayıdaki istisnalar dişında Türkçü olarak bilinenleri de İslamcı olarak bilinenleri de Türklük ve Müslümanlık siyasetlerinin her ikisini birlikte savunuyorlard. Aralarındaki fark, Türkçülerin İslamcılara göre Türklügü çok daha belirgin biçimde vurgulamasıydı. İşte bu Türkçüler, ilk Türk-İslam Sentezcileri olarak değerlendirilmektedir. Alkan'ın, İkinci Meşrutiyet'ten başlayıp 1918 yılına kadar süren on yıllık dönem içinde, II. Abdülhamid devrinde geçerli olan "İslami-Türk Sentezi"nden "Türk-İslam Sentezi"ne geçiş şeklinde gerçekleştiğini ileri sürdüğü ideolojideki değişim, doğru olabilirse de bu değişim bizim konumuz açısından çok önem taşımamaktadır (Alkan, 2014). Zira hem Abdülhamid'in kişiliğinden hem de o zamana kadarki devlet geleneği ve bürokratik birikimden dolayı Sentez'de İslam'ın o dönem için daha ağırlıklı olması, nihayetinde ortada bir sentezin bulunduğu gerçeğini ortadan kaldırmamaktadır.

Cumhuriyet' in kurulmasından sonra üç tarz-1 siyasetten farklı bir siyaset, inkılapçılık ve garpçlık siyaseti devletin temel politikası olarak benimsenince Osmanlıcılık fiziki imkansızlığın etkisiyle artık yok olmuş, İslamc1lık ise yasaklanmış iken Türkçülük belli oranda da olsa kendine bir yer bulabilmişti. Fakat bu Türkçülük genel olarak daha öncekinin aksine Müslümanlık siyasetini dışlayan bir şekle bürünmüştü. 1960'lı yıllara gelindiğinde "Sentez" bilinçli ve organize şekilde yeniden oluşmaya başladı. 1970'li yıllarda Milliyetçi Cephe (MC) hükümetleri ile hükümet politikalarına yön 
veren Türk-İslam Sentezi, 1980 'den sonra ise hem ihtilal yönetimi hem de Özal Hükümetleri döneminde devlet politikalarına yön vermiştir.

Günümüzde yine devletin "beka" sorunuyla ilintili biçimde Türk-İslam Sentezi, "Cumhur İttifakı" olarak hükümet politikaların belirlemekte, devleti bizzat yönetmektedir. Bununla birlikte bir Türk-İslam Sentezi olarak Cumhur İttifakı, öncüllerinden iki açıdan farklılık taşımaktadır. İlk farklılık, öncüllerde sentezi oluşturan unsurların tarihten gelen bir iç içe geçmişliğiyle sentez tam bir bireşim, hatta yeni bir tez haline gelmişken, diğerinde tez haline gelmiş bir sentezden, bireşimden bahsedilemez. İkinci farklılık ise, öncüllerde Sentez' in varlığı daha ziyade bilimsel ve akademik çaba ve kaygilarla gündeme getirilirken, diğerinde Sentez, devletin bekasına ve idaresine ilişkin siyasi çaba ve kaygılarla ortaya çıkmıştır. Bu iki farklılığıyla Cumhur İttifakı Türk-İslam Sentezinin özgün bir örneğini teşkil etmektedir.

Dolayısıyla Türk-İslam Sentezi ve Türk-İslam Sentezcileri, yüz yılı aşkın süredir Türk düşünce ve siyasi hayatında etkisini ve etkinliğini sürekli olarak göstermeye devam etmekte olup, geçmişi olduğu gibi günümüz fikir ve politik hayatını da anlama ve açıklamada incelenmesi ve araştırılması büyük önem taşımaktadır.

Bu çalışma, "Türk-İslam Sentezcilerinde Din" adlı doktora tez çalışmamızdan üretilmiş olup, Türk-İslam Sentezinin ne olduğu ve Türk-İslam Sentezcilerinin kim olduğu konuları ile sınırlandırılmıştır. Araştırma yöntemi olarak nicel araştırma metodu kullanılmıştır. Gerek Türk-İslam Sentezcilerinin gerekse Türk-İslam Sentezcisi olmayanların konuya ilişkin eser ve yazıları dolaylı gözlem yöntemiyle ele alınmıştır. Literatür taraması yoluyla ulaşılabilen kaynaklar derinlemesine incelenmiş, gözden geçirilmiş ve kuramsal bir derleme ile sunularak yorumlanmıştır.

\section{Sentez Kavramı}

Fransizca "bir araya getirme, bağdaştırma" anlamındaki synthèse kelimesinden dilimize geçmiş olan sentez, Türk Dil Kurumu'na göre "Yalından karmaşık olana, külliden cüziye, zorunludan olasıya, ilkeden onun uygulanmasına, genel yasadan bireysel duruma, nedenden etkiye, öncülden varllan sonuca giden düşünme biçimi, bireşim" anlamına gelmektedir. Sentez kavramı sahip olduğu anlam genişliği ve kullanışlılığıyla, tez ve antitez üretmekten çok daha fazla, üretilmiş olan tez ve antitezleri kullanma eğiliminde olan son iki yüzyıllık Türk 
düşünce ve siyasi hayatında, kullanıldığını ya da var olduğunu en sık gördüğümüz kavramlardan biridir. Hemen hemen her kesimden pek çok düşünce akımı veya adamı ile siyasi oluşum veya figürün kendi anlayışları çerçevesinde ve engin kombinasyon çeşitliliğiyle sentez yaptıkları veya senteze ulaşmaya çalıştıklarını iddia ettikleri görülmektedir. Türk-İslam Sentezcilerinin kullandığı kavramlarla söylenirse, ulaşılmak istenen "ülkü" veya "mefkure", içerdiği öğeler itibariyle mahiyet açısından farklılaşsa da, değişik öğeleri ayrı tonlarda "terkip" veya "inşa" etmesi itibariyle yapım açısından aynılaşmaktadır.

Türk-İslam Sentezcilerinin sentez sözcügüne alternatif olarak kullandıkları terimlerden olan ülkü ve terkip sözcükleri hem kelimenin sözlük anlamıla ulaşılmak istenen bir ülküyü ve var olduğu veya var edilmesi gerektiği savunulan terkibi hem de özel anlamıyla "ülkü"yü ve "terkib"i ifade etmektedir. Yani ülkü Türk-İslam Ülküsünü, terkip ise Türklük ve İslam'ın terkibini ifade etmektedir. Ayrıca her iki terim de ortaya çıkmış olan, var olan sentez hali anlamıla statik; sentezleme, sentez yapma anlamıla dinamik açlardan sentez kavramına gönderme yapmaktadır.

Ancak Türk-İslam Sentezcileri, kendileri ve ideolojileri için "sentezcisi" ve "sentez" kavramlarını kullanmaktan genel olarak kaçınmaktadırlar. Bunda Türkiye'de özellikle 1960 sonrasının çift kutuplu ideolojik yapılanmasının etkisiyle, sentez kavramının Hegel ve Marx'tan alınan fikri mirasın hegemonyası altında, Türk sağı tarafından çoğu zaman olumsuz algılanmasınn etkili olduğu söylenebilir. Zira sentez Hegel'in, idealist felsefesini üzerine bina ettiği diyalektiğinde tez ve antitez zıtlığının zorunlu sonucuydu. Her tez zorunlu olarak antitezini yaratacak, böylece ortaya çıan tez-antitez zıtlığ 1 sentezi oluşturacaktı. Bu oluşan sentez de yeni bir tez olacak; bu süreç hep devam edecekti. Marx, Hegel'den aldığı, kendi ifadesiyle "baş aşağı duran" bu diyalektiği, diyalektik materyalizm haline getirerek "ayakları üzerine dikerken" de sentezin Hegel'deki anlamını korumuştu. Mamafih, Hegel'den daha ileri giderek tüm varlığı ve tarihi bu tez-antitez-sentez şeklindeki zorunlu döngüsellikle açklamıştı. Böylece sentez, Marksizm'in varlığı ve tarihi açıklamasında anahtar kavramlarından biri olmuştu ki, bu haliyle Türk sağınca Türk-İslam Sentezi biçiminde bir tamlama oluşturması kabullenilemezdi. Nitekim Türk-İslam Sentezcilerinin önde gelenlerinden Seyyid Ahmed Arvasi bu durumu şöyle açıklamaktadır: “... 'sentez', tez ile antitez arasında söz konusu olacağına göre, yıllardan beri kullandığımı 'Türk- 
İslam Sentezi' yerine, 'Türk-İslam Ülküsü' sözü daha uygun olur."(Arvasi, 1979, s.10). Amiran Kurtkan da benzeri bir tavırla şöyle demektedir: "Türk-İslam tabiri bir sentez değildir. Ama, bu iki tabirin birbirinden ayrulmast da asla caiz değildir. Çünkü, İslam'ın özü (felsefesi) Türklü̈̆̈̈̈n Íslam'dan çok önce de benimsediŏi kendi prensibi olmuştur ve Türkler asırlar boyunca hiçbir milletin başaramadiğı şekilde İslamiyet'in bayraktarlı̆̆ın yapmışlardır."(Bilgiseven, 1990, s.106). Yine Zeki Arslantürk kendisi gibi Türk-İslam Sentezcisi olan hocası Orhan Türkdoğan'ın, sentez yerine milli-inşacı tabirini yeğlediğini ifade etmektedir: "Orhan Türkdoğan'm Türk sosyolojisini ekolleştirmedeki yeri "Türk-İslam Sentezcileri", kendi deyimi ile "Milli ve Inşacı Sosyoloji" grubundadır. Zira ona göre birinci ayırm siyasi ve ideolojiktir. Halbuki ikinci ayırım bilimsel bir faaliyeti içerir." (Arslantürk, 2007, s.123-124).

Bununla birlikte Türk-İslam Sentezi tabiri Türk-İslam Sentezcilerince dışlanmış değildir, hatta azımsanmayacak kadar sık kullanılmaktadır. Örneğin bizzat Arvasi'nin bu tabiri çok kullandığı görmekteyiz: "Türk-İslâm Medeniyeti, Türk Milleti, Türk Gençliği ve gerçek Türk aydınları için vazgeçilmez, mukaddes ve yüce bir terkibin (sentezin) adıdır." (Arvasi, 1990b, s.264). "Türk-İslâm Medeniyeti, aziz Türk Milleti'nin mübarek bağrında yatan, muhteşem bir vakıadır. Hiç kimse, bu vakıayı inkâr ve ihmal edemez. Çünkü, bizi biz yapan bu terkiptir. Şimdi, bazılarn (içlerinde maalesef, Prof. ve Doç. etiketini kullanan cahillerin de bulunduğu bazıları), "Türk-İslâm Sentezi de ne demekmiş?... Cumhuriyet ve demokrasi sentezinden başka yol mu olurmuş?" kabilinden "akademik" (!) sözleri sarf edebilmektedirler."(Arvasi, 1990b, s.263).

Dolayısıyla sentez kavramının Türklük ve İslam ilişkisini veya birlikteliğini ifade etmekte kullanılabileceği, bizzat Türk-İslam Sentezcilerince de genel olarak kabul edilmektedir. Tartışmanın önemli olmadığı da yine onlar tarafından bizzat ifade edilmektedir: "Kelimeler üzerinde fazla durmayımz. Onlarm ifade ettiği mânâlara ve yöneldiği hedeflere önem veriniz. Bütün mesele, cemiyetimizi, kendi orijinal yapısı içinde, İslâm'ın imân ve ahlâkı ile yoğurarak, yeniden tarihî misyonu içinde yüceltmektir. Buna ister 'sentez', ister 'terkip' ister 'ülkü' deyin ne fark eder?"(Arvasi, 1990b, s.376).

\section{Türk-İslam Sentezinin Oluşum Süreci}

Türk-İslam Sentezinin kavram olarak kullanımı yaklaşık yarım asırlık geçmişe sahiptir. Bununla birlikte Türk-İslam Sentezcileri, Türk-İslam Sentezi- 
nin bir olgu olarak geçmişini Türklerin İslam'la tanıştığı zamana kadar götürmektedirler (Cebeci, 2001, s.34-35). Onlara göre zaten "İslâmî itikadlarla, eski Türk dini inanç sisteminin esasları arasında şaşılacak ölçüde bir mutabakat mevcut bulunmakta" (Kafesoğlu, 1985, s.160) olup, Türklerin İslam'la tanışmaları sonrasında bu şaşılacak ölçüde, hatta özdeşlik kurulabilecek derecedeki mutabakatın etkisiyle Türk-İslam Sentezi oluşmaya başlamıştı: "İ̧ste özdeşleşme vasfindaki bu belirtilerdir ki, İslâmiyet'i iyice tanıyan Türklerin artık kütleler hâlinde Müslüman olmaları neticesinde sosyal ve mânevi hayatm bütün cephelerinde Türk-İslâm kültür terkibi (sentezi) gerçekleşmiştir." (Kafesoğlu, 1985, s.161-162). Türk-İslam Sentezinin olgunlaşması süreci ise Türklerin Müslüman kimlikleriyle büyük kütleler haline bir araya geldikleri Horasan'da (Kafesoğlu, 1985, s.164), ve asıl olarak Anadolu'da tamamlanmıştır (Cebeci, 2001, s.38-48).

Etienne Copeaux, Türk-İslam Sentezcilerine göre Türk-İslam Sentezinin varlığını gösterebilmek ve hatta ortaya çıkabilmek için inanç ve kültür kaynaşmasından daha fazlasına, bir devlet yapılanmasına ihtiyaç duyduğunu, bunu sağlayanın ise ilk Müslüman Türk devletleri olduğunu söylemektedir: “Aral Denizi'nden İran Körfezi'ne, Anadolu'dan Indüs'e kadar uzanan çok geniş bölgeye, yazarlar Tolunoğulları (9. yüzyıl) ve İhşidi hanedanlarmın (10. yüzyll) "Türk" Misır'ın da eklemektedirler. Burada da, o dönemin Misırl yorumuna her zaman uymayan ve Mısır tarihine tamamen Türklük açısından yöneltilmiş bir bakış söz konusudur. Türk tarihçilerin gözünde, bu iki alanın birbirine eklenmesiyle "ilk Müslüman Türk devletleri" tanımlanmış olur. Türkler, en azından biçimsel olarak, İan ve Arap toplumlarnn yönetimini ele geçirmişlerdir ve bu toplumlara kendi kişiliklerini kazımaktadırlar: Bu ilk Türk-İslam sentezidir; tek eksik, o sırada hâlâ Ermenilerin ve Bizanshların elinde bulunan, Anadolu toprağıdır." (Copeaux, 1998, s.149-150). Türk kimliği ve düşüncesinde devlet kavramının sahip olduğu merkezi ve belirleyici konum düşünüldügünde, Türk-İslam Sentezi'nin oluşumu ya da en azından olgunlaşması için bu sentezi doğrudan ya da dolaylı biçimde destekleyen bir devlet yapılanmasının gerekliliği yadsınamaz. Nitekim Türk-İslam Sentezi'nin kavram olarak kullanılmasının kronolojisi göz önüne getirildiğinde MC hükümetleri ve Özal hükümetleri ile günümüzde Cumhur İttifakı dönemlerinin, Türk-İslam Sentezinin en çok gündeme geldiği ve tartışıldığı dönemler olduğu görülecektir.

Türk-İslam Sentezcilerine göre İlk Müslüman Türk Devletleri ile oluşma ve olgunlaşma devresini tamamlamış olan Türk-İslam Sentezi, Selçuklular 
ve Osmanlı dönemlerinde Türk ve İslam kimlikliklerinin birbiriyle tam anlamıyla birleşerek tek kimlik olmasıyla, neredeyse bir tez haline gelmiştir (Bilgiseven, 1995, s.41). Hatta öyle ki, ortada artık ayrıştırılsa yok olabilecek bir bireşim söz konusudur: "Türk Islâm Sentezi fikrine 19. yüzyılın sonunun ilk milliyetçi yazarlarımın çalışmalarında olduğu gibi, Ziya Gökalp'inkilerde de rastlanilabilir. Bu fikir, Türklük ve İslâm arasında mükemmel bir uyum olduğunu öngörür. Buna göre, İslâm'ı kabul etmek Türklerin kaderi olduğu; onlar olmasaydı bu dinin ya felç ya da tükenmiş olacă̆ı; pek çok halkın İslâm'a kazandırılmasımı să̆ladıkları için Türklerin dinin kalkanı ve kargısı olduklan iddia edilir. Buna karşılık, bu akıma göre, Türk kimliği kendini ancak İslâm içinde gerçekleştirebilirdi: İslâm'ı kabul etmeseydi, Türk kültürü yok olurdu." (Copeaux, 2005, s.46-47). Aynı şekilde Erkal (1990, s.100)'a göre Türk-İslam Sentezi'nin farklı bir yönünü temsil eden Yahya Kemal'in, "Ta ki yükselsin ezanlarla müeyyed nâmın / Gâlib et, çünkü bu son ordusudur İslâm'ın" dizeleri de bu durumu yansitmaktadır. Aslında son devir Osmanlı ve erken dönem Cumhuriyet düşünsel ve politik hayatında Türk ve İslam kimliklerinin sözünü ettiğimiz bireşimi "millet" kelimesiyle ifade ediliyordu. Dinsellik ve ulusallık kavramlarının ikisini birden içeren millilik ve millet kelimelerinin bu özelliğinin ortaya çıktı̆̆ı en ilgi çekici örneklerden birisi, 30 Ocak 1923 tarihinde imzalanan Yunan ve Türk Halklarının Mübadelesine Dair Sözleşme'de Türklük ayrımının ırka göre değil, dine göre yapılmasıdır.

Osmanlı'nın son zamanlarında Ziya Gökalp'in başını çektiği Türkçü düşünür ve yazarlar kendilerine kadar yapılmayanı yaparak Türk-İslam Sentezini analiz etmeye, bireşimin elementlerini anlamaya ve açıklamaya çalışmışlar, onu bir olgu olmanın ötesine taşıyarak ideoloji haline de getirmişlerdi. Dönemin özelliği gereği sentezin İslam öğesi, diğerine göre daha etkin ve baskın biçimde ifade edilebilirken Türk öğesi, İttihat ve Terakki'nin cüretkar politika ve söylemlerine rağmen daha dengeli dillendiriliyordu. Ancak Cumhuriyetin ilanından sonra durum tersine dönerek, sentezin İslam öğesi mahcup bir şekilde ifade edilmeye başlandı. Sonunda sentez, Gökalp ve arkadaşlarının “Türkleşmek, İslamlaşmak, Muasırlaşmak”ından İslamlaşmanın çıkarılmasıyla başka bir şekle dönüştürülmek istendi. Devlet eliyle desteklenen bu dönüşüm, Türk kimliğinin İslam kimliğinden sıyrılarak anlaşılması gerektiğini iddia eden görüşlerin ortaya çıkmasına neden oldu. Böylece sentezin, bileşenlerinin birbirlerinden ayrılmasıyla tez ve antitez zitlı̆̆1 çerçevesine oturtulup bozulduğu dönem başladı. 
Çok Partili döneme geçilmesiyle birlikte dönemin görece özgür ortamında kendilerini daha rahat ifade eden milliyetçiler ile muhafazakârlar arasındaki derinleşen yarılmayı önleme çabası, tevarüs ettiği milliyetçi ve muhafazakâr birikimin üzerinden Türk-İslam Sentezini gündeme getirdi. Türkİslam Sentezinin günümüzdeki görünümüyle oluşumunu sonuçlayacak süreci başlatan öncelikli etken Erol Güngör'e göre, 30 ylllık inkılapçllık deneyiminin başarısızlığında ve milliyetçilerce bu başarısızlığın müsebbibi olarak değerlendirilen sorunları çözme isteğinde yatıyordu: "Milliyetçilerin birleşmesinden ne anlaşıllyordu ve bu birleşme niçin lüzumlu görülüyordu? Her şeyden evoel, inkılâpçıllk cereyanı memleketin meselelerini çözmekte başarısız kalmış ve bu cereyan temsil eden siyasî kadro millet tarafindan tasfiye edilmişti. İnkılâpç-lar yavaş yavaş kendileri için mukadder olan istikamete, yani sola doğru kayarlarken bunlarm karşısında millî kültürün müdafaasın yapanlar yeni Türkiye için milliyetçi bir görü̧ş bulmak zorundaydılar. Bu yolda atılacak ilk ve en büyük adım, Türk milletinin kültür kıymetlerini ortaya çıkarmak ve onlar etrafinda bir millî birlik kurmaktı." (Güngör, 1999, s.137).

İkinci etken, inkılapçıların yaptıklarının tersine, Gökalp ve arkadaşlarının savundukları gibi millete ve milletin değerlerine gitmek denilebilecek bir tavır alıştı: "İnklâpçılar Türk milletini tanımaktan ziyade onu ideal edindikleri bir kalıba sokmakla uğraşmışlard. Milliyetçiler bunun tam tersine bir yol tutturdular ve millet hangi kahbı almak istiyorsa ona bu istikamette yardımo olmayı prensip edindiler. Millete döndükleri zaman onda şu iki ana hususiyet gördüler: Bir defa İslâm dini bizim milliyetçiliğimizin en mühim bir unsuruydu ve onun ihmal edilmesi için hiçbir ciddî sebep de mevcut değildi. Diğger taraftan, bizi başka Müslüman cemiyetlerden ayıran pek çok hususiyetlerimiz vardı ki, bunlar da bizim ayr bir millet halinde teşekkül edişimizden, yani Türk olmamızdan ileri geliyordu. Şu halde Türklük ve Müslümanlık birbirinden ayrn şeyler olarak düşünülemezdi. Yapılacak iş, bu unsurlardan birine bilhassa önem vererek diğerini ihmal eden milliyetçi liderleri bu noktada birleşmeye davet etmekti." (Güngör, 1999, s.138).

Üçüncü etken ise özellikle İkinci Dünya Savaşı sonrasında değişmeye başlayan dünyanın ve yeni kurulan dünya düzeninin gençler üzerindeki etkisiydi: "Yeni bir dünyanın çocukları olan ve yeni meselelerle karşılaşan gençler kendilerini tatmin edecek bir sistem ve bir şahsiyet bulamadıklar için, ayrn ayr faydalandıkları ve bağllık gösterdikleri fikir liderlerini bir araya getirebildikleri takdirde milliyetçi hizipleri de toparlayabileceklerini düşündüler. Böylece 1950-1960 
devresi milletin teşekkülünde İslâmî kıymetlere ağırlık verenlerle Türkçüleri birleştirme çabaları içinde geçti." (Güngör, 1999, s.137).

Sonuç olarak sentezin her iki öğesini tekrar bir araya getirme çabaları 1960'lı yıllarda yavaş yavaş sonuç verecek ve ilk defa Türk-İslam Sentezi olarak da isimlendirilecektir. İlk isimlendirmenin tarihi olarak 1978 yılı (Güzel, 2006), 1970'li yılların ortaları (Kafesoğlu, 1985, s.XII) gibi genelde MC hükümetleri dönemleri zikredilse de, Boyunağa (1975)'nın Türk-İslam Sentezi adıyla yazdı̆̆ı kitabın ilk baskısının 1970 yılında yapıldığı göz önüne alındığında Türk-İslam Sentezi ifadesinin 1960’lı yıllarda kullanılmaya başlandığı söylenebilir.

\section{Türk-İslam Sentezine Yönelik Eleştirilere Verilen Cevaplar}

Türk-İslam Sentezi'nin, tarihin doğal akışı içerisinde ve toplumsal şartlar doğrultusunda kendi kendine oluştuğunu öne süren Türk-İslam Sentezcilerinin bu görüşleri Türk-İslam Sentezcisi olmayan veya onlara karşı olanlar tarafından pek kabul görmemektedir. Bunlara göre; "Türk-İslam Sentezi düşüncesinin, iddia edilenin aksine, Türk sağının Türklük ve İslamcılık kanadın birleştirmek ve/veya Müslümanlığı millet düşüncesi içine sı̆̆dırmak amacıyla değil de, bir irkl - milliyeti ifade eden alt kimlikleri İslam potasinda eritme hedefiyle bir hegemonya projesi olarak Türk toplumunun dünyaya bakışını, dönemindekinden daha fazla etkileme amactyla hareket ettiği kuvvetle ileri sürülebilir." (Çağlar ve Uluçakar, 2017, s.137).

Bu görüşte olanlar genellikle Türk-İslam Sentezini devlet eliyle kurgulanan bir politika olarak görmektedirler: "Türk-İslam Sentezi, 12 Eylül yönetiminin, Türkiye Cumhuriyeti'nin temel dünya görüşünü oluşturan pozitivist ve laik eğitim ve kültür politikasına karşı, Aydınlar Ocă̆ı'nın işbirliğiyle uyguladığı eğitim ve kültür politikasıdır. Bu politika, özellikle ANAP iktidarları döneminde, Beşinci ve Altıncı Beşer Yillık Kalkınma Planları'nın uygulama programların oluşturan ve Devlet planlama Müsteşarliğınca hazırlanan Milli Kültür adlı bir raporla uygulamaya konmuştur." (Timuroğlu, 1991, s.4). Timuroğlu (1991) ile Güvenç, Şaylan, Tekeli ve Turan (1991)'a göre bu kurgunun oluşturulması ve uygulanabilmesi için yabancı güçlerin de desteği alınmış; böylece uluslararası emperyalist güçlerle 12 Eylül yönetiminin işbirliği sonucu oluşturulan "1rkçı", "gerici”, "bilim ve Atatürk karşıtı" ve "çağ dışı" Türk-İslam Sentezi, Türkiye'yi emperyalizmin kıskacına sokmak amacıyla kullanılmaktadır. 
Diğer yandan Türk-İslam Sentezi karşıtı olup da Sentezin 1980'in hemen öncesi veya hemen sonrasında kurulmadığını, Osmanlı'ya dayanan köklerinin olduğunu ifade edenler de bulunmaktadır (Ölçen, 1994, s.180).

Dışarıdan bir gözlemci niteliğiyle konuyu inceleyen Copeaux (2005, s.47) ise, Türk-İslam Sentezi'nin soğuk savaş yıllarının şartlarında milliyetçi seçkinlerce üretilen, Türk milliyetçiliğine İslami değerleri eklemlemek isteyen ve Kemalist mirası tamamen reddetmeyen bir akım olduğunu ifade etmektedir. Kemalist mirasın reddedilmemesi meselesi önemlidir, zira Türk-İslam Sentezcileri ile 12 Eylül yönetimi arasında, sınırlı da olsa işbirliği yapılabilmesinin önünü açan nedenin, Sentezcilerin bu özelliği olduğu söylenebilir. İslâm'ı komünizme karşı bir duvar olarak kullanmak isteyen 1980 Askerî Darbesinin bu noktada işbirliği yapabileceği en uygun akım, Türk-İslam Sentezi idi. Darbe hükümetinden sonra işbaşına gelen Özal hükümetleri döneminde ise bu işbirliği neredeyse her alanda ağırlığını ortaya koymuştu.

Dine işlevsel açıdan yaklaşan 12 Eylül yönetimince İslam, komünizme karşı duvar olarak kullanılmak istendiği gibi, toplumsal birlik ve beraberliği sağlayabilecek kurum olarak da kullanılmak istenmiştir. Nitekim darbenin lideri Kenan Evren, askeri darbenin üzerinden henüz 4 ay geçmişken 17 Ocak 1981 tarihinde Kahramanmaraş'taki halk mitinginde "Hepimiz bir Allah'a inaniyoruz, bir Peygamberimiz var, aynı Kur'an'ı kullanıyoruz, ayn Kur'an'ın sureleriyle namaz kılıyoruz. O halde ayrnlık neden!" diye konuşmuştu. Bu noktada darbe yönetiminin yardım alabileceği ve işbirliği yapabileceği belki de tek akımın, akademisyenlerden ve yazarlardan oluşan seçkin yapısı, Atatürk'e saygılı bakışı ve dinin işlevsel özelliklerini vurgulayan yaklaşımı ile bilhassa Aydınlar Ocağı'nın temsil ettiği Türk-İslam Sentezi olmasında şaşlacak bir şey yoktu.

Türk-İslam Sentezcileri ile Türk-İslam Sentezcisi olmayan veya karşıtı olanlar arasındaki en büyük tartışma konularından birisi olan, Türk-İslam Sentezinin bir yeni-üretim olup olmadığına dair tartışmada Aydınlar Ocağı kilit noktalardan biridir ki bu durumu Aydınlar Ocağı'nın kurucu üyesi ve ilk başkanı olan Kafesoğlu (1985, s.XII) şöyle ifade etmektedir: "Bir ilim ve kültür müessesesi olan Aydnlar Ocă̆ı, verdiği pek çok hizmetler yanında Türk'ün ne ve kim olduğu meselesine de eğilmiş, buna doğru ve şaşmaz cevaplar aramıştır. Haddizatında bu sualin cevabı Türk'ün son 1000 senelik tarihinde, bugün yaşanan en küçük köyündeki minareden, büyük kültür ve medeniyet merkezlerindeki çeşmeler, hamamlar ve kubbelere kadar her yurt parçasinda mevcuddur. Keza bu sualin 
cevabı pek çok düşünür ve sanatkârının ifadelerinde de bulunmaktadır. ... Aydınlar Ocağı mensupları bu düşünce ve duygularla Türk'ün İslâm'da, İslâm'ın Türk'te bütünleştiğini müşahede etmiş ve bu hali bizzat yaşamışlardır. Bundan dolayı son 10 senedir onlar «İslâm-Türk Sentezi» veya «Türk-İslâm Terkibi» ifadesini sık olarak kullanırken Türk'ün varlk hikmetini de işaret etmiş oluyor."

Dolayısıyla Aydınlar Ocağı'nın 1970'li yıllardan itibaren Türk-İslam Sentezini besleyen kaynaklardan biri olduğu, bir kısım Türk-İslam Sentezcilerini bir araya getirdiği ve Türk-İslam Sentezini 80'li yıllarda politik ve bürokratik arenada etkili ve güçlü hale getirmede önemli rol oynadığı görülmektedir. Ancak bu rolün Türk-İslam Sentezinin üreticisi olmaya kadar çıkıp çıkmadığı tartışmalı bir konudur. Türk-İslam Sentezinin yeni-üretim olduğu anlamına gelecek böyle bir üreticilik rolü Aydınlar Ocağı olmak üzere hiçbir Türk-İslam Sentezcisi tarafından tabii ki kabul edilmemektedir.

Benzer şekilde Türk-İslam Sentezinin Marksist akımlarla savaşmak için kurulduğu iddiası (Copeaux, 1998, s.77) de Sentez'in bir yeni-üretim olduğunu ima ettiği için Türk-İslam Sentezcilerince kesin bir dille reddedilmektedir. Onlara göre Türk-İslam Sentezinin Marksist ve benzeri oluşumlarla savaştığı ortadadır, ama bu gerçek, Sentez' in bu amaçla üretildiği sonucunu doğuramaz; zira Türk-İslam Sentezi, düşünsel ve ideolojik açıdan Osmanlı'nın son dönemlerinde Türkçü ve İslamcı olarak tanımlanan, Cumhuriyet sonrası dönemde ise milliyetçi, muhafazakâr, ülkücü, mukaddesatçı, sağcı ve İslamcı gibi vasıflarla anılan aydınların ve siyaset adamlarının dile getirdiği fikir ve söylemlerin sentezinden oluşmaktadır. Bir vakıa olması açısından ise Türklerin İslam'la tanışmasından itibaren Türk tarihinin her aşamasında varlığını derinden duyuran (Kabaklı, 1990, s.78) ve Türklügün asırlardır sahip olduğu maddi-manevi tüm kültür ve medeniyet değerlerinin bileşkesidir (Bilgiseven, 1995, s.7).

Türk-İslam Sentezcilerinin, Türklük ile İslam ilişkisini sentez, terkip ve bileşke gibi kelimelerle nitelemesinin özel bir anlamı da Türk kimliğinin İslam'la birlikte yok olduğuna veya bozulduğuna yönelik olarak dillendirilen söylemleri reddetmektir. Onlara göre Türk kimliğine ait değerler Sentez'in teşekkülünde İslami kimliğe ait değerlerle aynı oran ve ölçüde yer almıştır. Türk kimliği, İslam'ı nasıl ki kendine özgü bir şekilde yorumlayıp sınırlı da olsa farklılaştırmışsa, kendisi de farklılaşmış, ancak özünü korumuştur. Hatta Cebeci (2001, s.34)’ye göre “Bazılarn Türklerin Müslümanlğ̆ kabullerinden sonra bir takım özelliklerini kaybettiklerini zannederler. Halbuki du- 
rum tamamen bunun tersidir. Ĕ̆ger Türkler bugün hâlâ mevcud iseler, bunu İslâm Dinine borçludurlar." Dolayısıyla Türk-İslam Sentezcilerine göre Türk-İslam Sentezi, Türklerin İslam'ı kabullerinden beri var olmaya devam eden normların öz bir ifadesini oluşturur: "Astrlardan beri bütün Türk Devletlerinde her şeye hakim olan İslâm inançlarn ile Türk töreleri bizi bu güne kadar getirmiştir. Yani Türk-İslâm Sentezi bizim asırlardır yaşamakta olduğumuz normların veciz bir ifadesidir." (Cebeci, 2001, s.37)

\section{Türk-İslam Sentezcisi Kimdir?}

Türk-İslam Sentezcilerinin büyük çoğunluğunun akademisyen olması, onların kendilerini ve Sentez'i çoğu zaman dışarıdan bir gözlemci gibi ve akademik üslupla tanımlamalarına neden olmuştur. Akademik üslup ve kayg1lardan uzak, daha rafine yapılmış tanımlamalar ve açıklamalar için başvurulacak nadir Türk-İslam Sentezcilerinden biri olan Seyyid Ahmet Arvasi'nin özellikle gazete yazılarından derlediği kitapları bu noktada oldukça zengin verileri barındırmaktadır.

Başlıktaki soruyu Arvasi (1991, s.202) özet olarak ve ayrıntılara girmeden şu şekilde cevaplamaktadır: "Ben, İslam iman ve ahlakın yaşamaya ve yaşatmaya, Türk-İslam kültür medeniyetini yeniden ihya etmeye inanmış MüslümanTürk'üm." Bu tek cümlelik öz tanımlamada, İslam ve Müslüman kelimelerinin üç defa geçerken Türk kelimesinin iki defa geçmesinin bilinçli bir tercihi gösterdiğini ispat etmek mümkün olmasa da, bilinçsiz bir dışavurumla Sentez'i oluşturan unsurların oranların gösterdiği söylenebilir. Gerçekten de, her ne kadar bu tarz soyut olgularda rakamsal ölçekler kullanılamayacak olsa bile, Sentez'de 2'ye karşı 3 ölçekle İslam öğesinin daha baskın olduğu rahatlıkla söylenebilir. Nitekim onun şu sözlerinde bu durum belirgin biçimde ifade edilmektedir: "Bu kitabın yazarı, bir terbiyecidir. O, bütün hayatı gibi, mesleğini de Allah ve Resulü'nün hizmetine vakfetmiş bulunuyor. Ona göre, son nefesine kadar bu yolda yürümek ve son nefesini bu uğurda vermek, nimetlerin en büyüğ̈̈̈ olacaktır."(Arvasi, 1983, s.5)

Tevarüs edilmiş bir kimlik olarak "Müslüman-Türk"lükten, bu kimliğin bilinçli ve aksiyoner biçimde, belli gayeler için oluşturulan ve kullanılabilen haline, yani Türk-İslam Sentezciliğine/Ülkücülüğüne geçiş, Arvasi (1990b, s.347)'ye göre yükseköğrenim imkanının tabana yayılması ve böylece kimliğin habersiz sahiplerinin yüksek öğrenim görmesiyle gerçekleşmiştir: "Bi- 
zim ülkemizde de tahsil imkam bulan tertemiz Müslüman-Türk çocukları, meseleye el koydu: Adeta yeni baştan ve büyük bir heyecanla Türk-İslam kültür ve medeniyetini keşfetti ve bu terkibin ifade ettiği manayı kavradı. Yüksek tahsil kademesinden de geçen bu tertemiz nesil, içinde yaşadı̆̆ı zaman ve mekanın şart ve imkanlarını da kollayarak bu yüce terkipten gelecek zamanları fethedecek bir kültür ve medeniyet politikasına ulaştı ve buna Türk-İslam Ülkücüsü adını verdi." Türk-İslam Sentezcisi kimliğinin oluşumunda yükseköğrenim görmüş olmanın ve olanların rolü, kimliğin temel niteliklerinden olan akademik eğilimin nedenini açıladığ1 gibi, muasırlaşma, çağdaşlık, inkılapçılık veya batılılaşma sorununun Sentez açısından "barışçıl” bir yolla çözümünü zorlamıştır. (Arvasi, 1986)

Sözü edilen zorlayışın Arvasi (1990a, s.5)'yi, muasırlığı neredeyse Sentez'in bir öğesi konumuna sokmaya ittiği görülmektedir. Nitekim Arvasi (1979, s.217) bu açıdan Türk-İslam Sentezini ve Sentezcilerini şöyle tanımlamaktadır: "yabancılaşmadan çă̆daşlaşmayı esas alan, milli ve dinamik bir harekettir. Biz hem Türk, hem Müslüman, hem de medeniyiz." Bu tutumun daha silik izleri, onun demokrasiye bakışını ifade ettiği şu sözlerinde de takip edilebilir: "Beni dosdoğru tanımanızı isterim. Ben, İlam iman ve ahlakına bağh bir Türk Milliyetçisiyim. Demokrasiye ve çok sesliliğe inanırım. Bunun yanında mücadelemi, anayasa ve yasalar içinde sürdürmeyi prensip edinmiş bulunuyorum. Anayasaya uyarak anayasayı, yasaya dayanarak yasaları değiştirmek mümkündür. Bunun da yolu demokrasiden geçer; ben ihtilalci değilim." (Arvasi, 1996, s.96)

Böylece Arvasi' de gözlemlediğimiz üzere geç dönem Türk-İslam Sentezcileri, ilk dönem Türk-İslam Sentezcilerinin ortaya koyduğu ve Gökalp'in Türkleşmek, İslamlaşmak, Muasırlaşmak şeklinde ifade ettiği formülü kabul etmektedirler. Ancak burada Sentezin İslam öğesine ilişkin olarak iki farklılık göze çarpmaktadır.

Birinci farklılık, İslam'ın Sentez'deki konumudur. Arvasi'nin ve genel itibariyle ilk dönem Sentezcilerin kabul ettiği Sentez'de İslam öğesinin ağırlı̆̆1 çok daha belirgindir. Örnek olarak Arvasi (1980, s.277)'nin Türk-İslam Sentezcisini tanıttı̆̆ı şu sözlerinde bu durum açıkça görülmektedir: " $O$, İslam'ın iman, aşk, ahlak ve aksiyonuna sahiptir; onun şahsi dostu ve düşmanı yoktur; onun dostluğg da, düşmanlı̆̆ı da Allah içindir. O, devletini de, milletini de, bayră̆ım da Allah için sever ve yüceltir. Onda İslam basireti ve Türk'ün haysiyeti vardır." Arvasi (1979, s.238) daha da ileri giderek en temel milli unsurların, değerlerini dinden aldıklarını söyler: "... İslamiyet, Allah'ın dini; kurtarıcımız ve Kâinatın Efendisi Allah'ın Resulü; Şanlı Türk Milleti Allah'ın Islam'a hizmetle 
şereflendirdiği millet; Türk ordusu Allah'ın ordusu; Türk bayră̆ı mukaddes ay ve yıldızı ile yüce İslam'in ve al rengi ile Allah için can veren şühedanın kanlarmın ifadesidir. Üzerinde ezan-ı Muhammedi okunan aziz vatanımı ise, İslam'tn ebedi güneşinin hiç batmadığı en büyük ümit ve hayat kaynağımızdır." Bu sebeple Türk-İslam Sentezcileri düşünce dünyalarını da İslami referanslara dayanarak oluştururlar: "Türk-İslam Ülkücülerinin fikir sistemi Allah ve Resulünün çizgisinde yürüyen akl-ı selim sahibi, bir yüce veliler ve mütefekkirler kafilesince yoğrulmuştur." (Arvasi, 1979, s.25). Yine irkçlıktan kaçınma noktasında Arvasi'nin hassasiyeti, Sentez'deki İslam öğesinin ağırlı̆̆ına işaret etmektedir: "Ben, İslam iman ve ahlakına göre yaşamayı en büyük saadet bilen, Türk Milletini iki cihanda aziz ve mesut görmek isteyen ve böylece İslam' ' gaye edinen Türk milliyetçiliği şuuruna sahibim. Benim milliyetçilik anlayışımda asla ırkçılı̆̆a, bölgeciliğe ve dar kavmiyet şuuruna yer yoktur. İster azmliklardan gelsin, isterse çoğunluktan gelsin, her türlü ırkçılığa karşıyım. Bunun yanında Şanlı Peygamberimizin "kişi kavmini sevmekle suçlandirlamaz. Kavminin efendisi, kavmine hizmet edendir. Vatan sevgisi imandandır" tarzında ortaya koydukları yüce prensiplere de bağglyım." (1990a, s.5)

İkinci farklılık ise İslam'ın mahiyetine ilişkindir ki, bu hususta "Hangi İslam?" sorusunu sordurabilecek bir farklılık bahis konusudur. Gökalp'teki İslam, yaşadığı dönemin İslamcı akımlarının da etkisiyle, dinde Kur'an'ın yerini genişletme ve Kur'an'dan alınan referanslarla dini anlayışı modern çağa daha "uyumlu" hale getirme çabalarına muhataptı. Mehmet Akif Ersoy'un "Doğrudan doğruya Kur'an'dan alıp ilhamı / Asrm idrakine söyletmeliyiz İslam'ı" şeklinde dile getirdiği bu tutumu Gökalp de temelde paylaşmaktaydı. Buna karşılık Arvasi (1980, s.304) ise Kur'an'dan ilhamın doğrudan doğruya değil; Peygamber, Peygamber'in arkadaşları (ashab), mezhep imamları ve İslam alimleri aracılığıyla alınması hususunda oldukça katı olup, dinde Sünnet'in (Peygamber ve ashabının söz ve uygulamaları) aleyhine olarak Kur'an'ın yerinin genişletilmesi çabalarını paylaşmamaktadır (Arvasi, 1989, s.229).

Bununla birlikte İslam'ı, "din” olmasına ilaveten ayn zamanda bir ideoloji olarak kabul ediş, Arvasi (1980, s.302)'de de vardır: "Türk milleti, asırlardan beri, İslamiyet'i, hem bir "din", hem de bir "ideoloji" olarak benimsemiş, kültür ve medeniyetini, bu ruh ve iman ile yoğurmuş bulunmaktadır." İslam'ı ideoloji olarak kabul edişin, diğer ideolojileri dışlama zorunluluğundan kaynaklandığ1 söylenebilir. Zira Arvasi (1980, s.449)'ye göre Türk-İslam Sentezcileri 
"kapitalist ve komünist sistemlere karşı olduğu kadar faşizme ve nazizme de karşıdır. Türk milliyetçileri, açıklayageldiğimiz üzere, tarihi tecrübelerinden, Türk-İslam kültür ve medeniyetinden, milli vicdan yoğuran mukaddes değer ve ölçülerden istifade ederek kendi sistemini kurmak zorundadır. O, milli ideolojisini, kendisi yoğuracaktır. Ona yabancı ideolojilerden bir hayır gelmeyecektir." Bu durum Türkİslam Sentezcisinin dünya konjonktüründeki yerini net olarak tayin etmektedir ki ona (1980, s.428) göre Türk-İslam Sentezcisi, "inananlar ile inanmayanlar arasındaki savaşta yerini almakla kalmamakta, inananlarm zaferiyle sevinmekte, yenilgisi ile sttrap duymaktadır."

\section{Sonuç}

Türk-İslam Sentezcilerine göre Türklük ile İslam arasındaki "sentez", tez ve antitez şeklinde birbirine zit iki unsur arasında değil, birbiri ile uyumlu iki olgu arasında gerçekleşmiştir. Türklerin İslam'dan önce sahip oldukları dini ve kültürel özelliklerin İslam'la uyumlu olması, bu sentezin doğal bir seyir halinde kendi kendine oluşması ve olgunlaşmasını sağlamıştır. Dolayısıyla onlara göre Türklerin İslam'la tanışmasından itibaren varlığını gösteren ve başta Osmanlı Devleti olmak üzere Müslüman Türk devletleri ile tam anlamıyla kıvamına ulaşmış olan Sentez, Türk-İslam Sentezine karşı olanların iddia ettikleri gibi politik amaçlarla kurgulanmış ve üretilmiş bir proje kesinlikle değildir.

Bununla birlikte onlar Türk-İslam Sentezciliğinin, asırlardır mevcut olan bu sentezi Müslüman-Türk kimliği biçiminde bilinçli olmadan kabulleniş ve yaşayışın ötesine geçerek, bilinçli, kuramsal ve ideolojik bir kabulleniş anlamına geldiğini kabul etmektedirler. Bu açıdan bakıldığında Osmanlı Devleti'nin son dönemlerinde Gökalp gibi Türkçü olarak tanınan aydınlar ve devlet adamları ilk dönem Türk-İslam Sentezcileri olarak anılmaktadır. Cumhuriyet' in kurulmasından sonra gündemden kalkan Türk-İslam Sentezi, 1960'lı yıllarda artan ideolojik kamplaşmanın ve öğrenci hareketlerinin etkisiyle tekrar düşünce ve siyaset sahnesinde etkinliğini göstermeye başlamıştır. 1970'li yıllarda, en radikalleri hariç olmak üzere "sağ"ın her iki yanının, Milliyetçi ve İslamcı tarafın, yanlarına "sağın ortası"nı da alarak hem politik arenada MC hükümetleri gibi birliktelikleri hem de fikri arenada Necip Fazıl gibi figürler ve Aydınlar Ocağı gibi platformlarla sağlanan birliktelikleri meydana getirmesi, Türk-İslam Sentezi'ni oldukça etkin bir 
konuma getirmiştir. 1980 Askeri İhtilalinden sonra ise bu etkin konum, devlet politikalarına yön vermeye kadar çıkmıştır. Günümüzde de Türk-İslam Sentezinin özgün bir örneği olarak Cumhur İttifakı devleti yönetmektedir.

Türkiye'de "İslamcı" ana akım siyasetin ilk iki partisi olan Milli Nizam Partisi ile Milli Selamet Partisinin adlarının başında "milli" kelimesinin geçmesi ve gençlik kollarına milliyetçi bir hassasiyeti de barındıran "Akınc1lar" ismi verilmesi tesadüfen olmadığı gibi günümüzde Adalet ve Kalkınma Partisi'nin de siyasi ve aksiyoner söylemini "yerli ve milli" olarak belirlemesi de tesadüf eseri değildir. Bu, Türk düşünce ve siyasi hayatında hem Gökalp çizgisinde ilerleyip günümüze gelen milliyetçi akımın hem de Akif çizgisinde ilerleyip günümüze gelen İslamcı akımın Türk-İslam Sentezini içerdiğini göstermektedir. Aradaki temel fark, Türklüğe yapılan vurgunun ağırlı̆̆ıdır. Ancak bu farkın görece küçüklüğü, İslamcı çizginin Türk-İslam Sentezcisi olarak isimlendirilmesini sağlayacağı da iddia edilemez.

Netice itibariyle Türk-İslam Sentezi gerek tarihten süzülüp gelen bir kimlik ve olgu olmasıyla tarihsel ve statik, gerekse politik ve fikri hayatı sürekli etkileyen hareket ve ideoloji olmasıyla güncel ve dinamik bir karakter taşımaktadır. Bu yönleriyle toplumsal hayat üzerinde etkin ve belirleyici bir konumu bulunan Türk-İslam Sentezine ve Sentezcilerine ilişkin sosyolojik inceleme ve araştırmaların artması toplumsal yapı ve değişim üzerinde daha sağlıklı analizler yapma ve sonuçlara ulaşma imkanı temin etmeye yardımcı olacaktır. 


\title{
EXTENDED ABSTRACT
}

\section{Formation and Development Process of Turkish-Islamic Synthesis}

\author{
Ahmet Selim Kadığlu \\ Memur Sendikaları Konfederasyonu (Memur-Sen)
}

The enlightened and the statesmen of the era mainly followed three ways regarding the "survival problem" of the Ottoman Empire, which were Ottomanism, Pan-Islamism and Turkism at the beginning of the last century. The policy of Ottomanism eliminated itself with the surfacing political events. The remaining two continued their existence in connection with each other. As a matter of fact, with the exception of the few, the ones known both as the Turkists and the Islamists defended the policies of Ottomanism and Pan-Islamism. The major difference between the two when compared to Islamists was that the Turkists emphasized being a Turk more explicitly. They were those Turkists that were regarded as the very first Turkish-Islamic synthesists.

After the foundation of the Republic, when the new policies of reformism and westernism, different from the the-three-way policy, were adopted as the fundamental policies, Ottomanism completely disappeared and Islamism was banned. However, Turkism, to a certain extent, managed to reserve a place of its own. The Turkism, unlike the previous one, took on a form that disregarded Islam. At the turn of the 1960s, the "Synthesis" started to reform in a deliberative and planned manner. In the 1970s, the Turkish-Islamic Synthesis led the government policies with the Nationalist Front (MC) government, and after the 1980s, it dominated the government policies both during the revolution government and the rule of Özal governments.

Today, in relation to the "problem of survival", the Turkish-Islamic Synthesis is still dominating the government policies as "The People's Alliance" and directly rules the government. As the Turkish-Islamic Synthesis, the People's Alliance differ from its pioneers in two ways. The first difference is that while the elements forming the synthesis in the former ones become a new synthesis with their interwoven past throughout history, a synt- 
hesis that has turned into a thesis is not applicable in the latter. Secondly, while the Synthesis emerges through more like scientific and academic efforts and concerns in the pioneers, it emerges through efforts and concerns regarding the survival problem of the government and the ruling of it in the latter. The People's Alliance sets a typical example for Turkish-Islamic Synthesis with its two differences.

Not only do the terms ideal and constitution used alternately by TurkishIslamic Synthesists as an alternative to synthesis lexically mean the ideals expected to be reached and the constitution that already exists or to be brought into existence, but also the "ideals" and the "constitution" with a particular meaning. In other words, ideals mean the Turkish-Islamic Ideal and constitution means the combination of being Turkish and Islam. Moreover, both terms refer to the concept "synthesis" both statically with their state of being a synthesis, and dynamically with a meaning of synthesize. However, Turkish-Islamic Synthesists generally avoid using the concepts of "synthesist" and "synthesis" for their own and ideologies sake.

According to Turkish-Islamic Synthesists, the "synthesis" between being Turkish and Islam does not occur on the basis of two contrary elements like thesis and antithesis, but two compatible phenomena. The compatibility of the religious and cultural traits that the Turks had before Islam has enabled this synthesis to emerge and mature naturally in its own course. According to them, the Synthesis that has made its presence felt since the Turks became acquainted with Islam and that has reached its heyday with Muslim Turkish governments, especially with the Ottoman Empire is not a project designed and produced with political concerns, unlike the opponents of Turkish-Islamic Synthesis have claimed.

In addition to this, they acknowledge that Turkish-Islamic Synthesism means the acceptance of this synthesis that has existed for centuries as Muslim-Turkish identity unknowingly and its going beyond their way of living, and then, turning it into a conscious, abstract and ideologic acceptance. From this standpoint, the enlightened and the statesmen known as Turkists like the Gökalps have been referred as the first Turkish-Islamic Synthesists. The Turkish-Islamic Synthesis that was abolished after the foundation of the Republic started to show its presence, in the 1960s, both in thought and politics with the increasing impact of the political polarization and student movements. In 1970s, the both sides of the "right-wing", except for the radicals, 
both the Nationalists and the Islamists siding with the "center-right" and forming the Nationalist Front (NF)government in the political arena and uniting literary figures such as Necip Fazıl, and creating platform like Intellectuals Center made the Turkish-Islam Synthesis come to the fore. After the 1980 military coup, its forceful status started to dominate the government policies. And today, the People's Alliance is ruling the government as a typical example of the Turkish-Islamic Synthesis.

It was not quite coincidental that the first two parties of the mainstream politics in Turkey the National Order Party and the National Salvation Party had "national" in their party names and neither was the youth branches called "Akinji", which embedded a national theme. And today, it is not purely coincidental either for Justice and Development Party (AKP) to dictate their political and actionary rhetoric as "domestic and national." This reveals that both the nationalist trend following the steps of Gökalps to date and the Islamic movement following its Active course to date referred in Turkish thought and politics include Turkish-Islamic Synthesis. The fundamental difference is the emphasis placed on being a Turk. However, a relatively minor difference of this is the fact that it cannot be claimed that it will enable the Islamic frontier to be called as Turkish-Islamic Synthesists.

Turkish-Islamic Synthesis can both be characterized as historical and static by being an identity and phenomenon carried throughout history, and up-to-date and dynamic by being an act and ideology affecting the thought and politics continually. By conducting further research on the TurkishIslamic Synthesis and Synthesists that play an effective and significant role on social life with such respect can contribute us to conduct more solid analyses and publish concrete findings on social structure and change.

\section{Kaynakça / References}

Alkan, M.Ö. (2014). Militarist Turkish-Islamic synthesis: Official 1deology, official history and nationalism in the second constitutional period. Türkiye Ortadoğu Çalı̧̧maları Dergisi, 1(2), 147-172.

Arslantürk, Z. (2007). Türkiye'de sosyoloji ve milli-inşacı Türk sosyologları. (Yayınlanmamış Makale).

Arvasi, S. A. (1979). Türk-İslam ülküsü 1. İstanbul: Türk Kültür Yayını.

Arvasi, S. A. (1980). Türk-İslam ülküsü 2. İstanbul: Türk Kültür Yayını. 
Arvasi, S. A. (1986). Doğu Anadolu gerçeği. İstanbul: Türk Kültürünü Araştırma Enstitüsü Yayınları.

Arvasi, S. A. (1983). Il m-i hal. İstanbul: Burak Yayınevi.

Arvasi, S. A. (1989). Türk-İslam Ülküsü 3. İstanbul: Burak Yayınevi.

Arvasi, S. A. (1990a). Hasbihal 1. İstanbul: Burak Yayınevi.

Arvasi, S. A. (1990b). Hasbihal 3. İstanbul: Burak Yayınevi.

Arvasi, S. A. (1991). Hasbihal 6. İstanbul: Burak Yayınevi.

Arvasi, S. A. (1996). Devletin dini olur mu? İstanbul: Burak Yayınevi.

Bilgiseven, A. K. (1990). Türkiye'de sosyal çözülme tehlikeleri. İstanbul: Filiz Kitabevi.

Bilgiseven, A. K. (1995). Türk-İslam kültüründe fert ve cemiyet ilişkisi ve İslami kavramlar. İstanbul: Filiz Kitabevi.

Boyunağa, Y. (1975). Türk-İslam sentezi: Dost ve düşman gözü ile. İstanbul: Yağmur Yayınevi.

Cebeci, D. (2001). Türk'e dair. İstanbul: Ötüken Neşriyat.

Copeaux, E. (1998). Türk Tarih tezinden Türk-İslam sentezine. (A. Berktay, Çev.). İstanbul: Tarih Vakfı Yurt Yayınları.

Copeaux, E. (2005). Türk milliyetçiliği: Sözcükler, tarih, işaretler. T. Bora (Ed.), Milliyetçilik (Modern Türkiye'de Siyasi Düşünce. Cilt 4 içinde (s. 44-52). İstanbul: Illetişim Yayınları.

Çağlar, A., ve Uluçakar, M. (2017). Günümüz Türkçülüğünün İslamla imtihanı: Türk-İslam sentezi ve aydınlar ocağı. Hacettepe Üniversitesi Türkiyat Araştrmaları (HÜTAD), 26 , 119-139.

Erkal, M. E. (1990) İktisadi kalkınmannn kültür temelleri. Ankara: Semih Ofset.

Güngör, E. (1999). Dünden bugünden, tarih-kültür ve milliyetçilik. İstanbul: Ötüken Neşriyat.

Güvenç, B., Şaylan, G., Tekeli, İ. ve Turan Ş. (1991). Türk-İslam sentezi. İstanbul: Sarmal Yayınevi.

Güzel, H. C. (2006, 26 Mayıs). Hedefteki yeni tip: Türk-İslam Sentezcisi. Radikal.

Kabaklı, A. (1990). Temellerin duruşması. İstanbul: Türk Edebiyatı Vakfı Yayınları.

Kafesoğlu, İ. (1985). Türk-İslam sentezi. İstanbul: Aydınlar Ocağı Yayınları.

Ölçen, A. N. (1994). İslam'da karanlı̆̆ın başlangıcı ve Türk-İslam sentezi. Ankara: Ekin Yayınevi.

Timuroğlu, V. (1991). Türk-İslam sentezi. Ankara: Başak Yayınları. 


\section{Kaynakça Bilgisi / Citation Information}

Kadıoğlu, A. S. (2020). Türk-İslam Sentezi'nin oluşum ve gelişim süreci. OPUS-Uluslararası Toplum Araştırmaları Dergisi, 16(27), 813-834. DOI: 10.26466/opus.699138 